\title{
AS (IN) CERTEZAS DA TECNOCIÊNCIA E O DIREITO: UMA ABORDAGEM NECESSÁRIA
}

\author{
THE (IN) CERTAINTIES OF TECHNOSCIENCE AND THE LAW: A NECESSARY \\ APPROACH
}

\author{
${ }^{1}$ Ester de Carvalho
}

\section{RESUMO}

O presente estudo visa compreender e traçar alguns delineamentos acerca dos desafios impostos ao Direito frente o desenvolvimento da Ciência e da Tecnologia modernas de modo a entender, com base na interdisciplinaridade que o tema exige e nos preceitos Bioéticos, as dificuldades afetas à resolução de conflitos tecnociêntíficos em tempos de (in) certeza. Partindo de uma investigação bibliográfica, busca-se uma abordagem que demonstre o alcance da tecnociência, dada a velocidade das modificações que propõe, e a dificuldade intrínseca das ciências jurídicas em fortalecer seus institutos de 'dever ser' em situações de risco e escassez de certezas.

Palavras-chave: Direito, Ciência, Tecnologia, Tecnociência, Bioética, Incertezas

\begin{abstract}
This study aims to understand and draw some outlines about the challenges to the law forward the development of science and modern technology to understand, based on interdisciplinarity that the subject requires and Bioethical principles, the afetas difficulties to solve technoscientific conflicts in times of (un) certainty. From a literature search, search is an approach that demonstrates the range of techno-science, given the speed of the changes it proposes, and the intrinsic difficulty of the legal sciences to strengthen their institutes 'should be' at risk and lack of certainty .
\end{abstract}

Keywords: Law, Science, Technology, Technoscience, Bioethics, Uncertainties

\footnotetext{
${ }^{1}$ Graduada em Direito pela Universidade do Vale do Itajaí, UNIVALI, Itajaí - SC (Brasil).

E-mail: ester decarvalho@hotmail.com
} 


\section{INTRODUÇÃO}

O estudo e abordagem das implicações trazidas pela tecnociência e, consequentemente, pelos novos direitos e deveres daí oriundos, é uma constante contemporânea. Nesta seara, a exploração técnico científica coloca-nos frente a uma nova era do conhecimento, na qual os riscos abstratos e as (in)certezas científicas devem ser, na medida do possível, amplamente conhecidos, debatidos e questionados.

Fruto da convergência de grandes áreas do conhecimento, ciência e tecnologia se unem e passam a transformar a maneira de refletir acerca do ser humano e sua relação com o meio ambiente, fazendo com que sejamos coadjuvantes de uma grande mudança comportamental e ambiental. Nesta seara pode-se vislumbrar, por exemplo, uma vertiginosa mudança de escalas, que perpassa da tecnologia de macroescala (da qual menos dependentes seremos) para a tecnologia da micro e nanoescala (da qual seremos cada vez mais dependentes), ou seja, tem-se uma significativa inversão de valores e proporções nunca antes imaginada.

A escolha do tema justifica-se em razão da necessidade de (re) pensarmos o futuro no que tange aos desafios lançados pela tecnociência e seus reflexos no Direito, utilizando-se como método de pesquisa a investigação bibliográfica.

Assim sendo, a impossibilidade de previsão quanto às consequências dos experimentos e aplicações tecnológicas introduzidas no quotidiano pós-industrial, e sua repercussão na qualidade de vida do homem e no meio ambiente, quando mensurados a médio e longo prazo, são questões que desafiam a própria técnica científica e, principalmente, a atual dogmática do Direito. Afastando-se da certeza e cada vez mais pautada em probabilidades, a tecnociência acaba por ditar as regras do dever ser do Direito, desafiando seus paradigmas frente à árdua tarefa de gerar e manter certezas.

Tais premissas movem a razão de ser deste artigo com vistas a entender, mesmo que diante de uma análise geral, este novo contexto tecnológico e científico, partindo de pressupostos básicos pautados no forte debate interdisciplinar existente entre a Ciência, a Tecnologia e o Direito, uma vez que esperanças e (in) certezas caminham juntas rumo a um futuro imprevisível. 


\section{O PAPEL DA CIÊNCIA E DA TECNOLOGIA NO SÉCULO XXI}

Tratar da ciência e da tecnologia atualmente significa entrar num universo, ao mesmo tempo, espetacular, abrangente e incerto. Cada vez mais somos submetidos a uma avalanche de novidades nestes dois grandes campos de conhecimento, que quando conjugados (tecnociência), traduzem uma força de criação cujas dimensões são inimagináveis.

Ao sairmos dos aspectos concretos da vida presente para darmos uma simples olhada no passado percebemos, além das significativas mudanças no modo de fazer ciência, uma ruptura com os paradigmas científicos, até então, tidos como imodificáveis. Neste ponto, o campo mais representativo desta ruptura concentra-se na medicina e suas áreas afins, de modo que o conhecimento científico aplicado aos assuntos referentes à vida, qualidade de vida, saúde e tratamento de doenças, fazem parte de um universo novo e único na história do conhecimento.

Desde os primórdios o homem se viu estimulado pelo conhecimento e compreensão dos processos naturais e biológicos, com vistas a melhor compreender a evolução das espécies e suas características peculiares, utilizando a observação como principal ferramenta de construção do saber.

Com isso, percorremos um grande caminho evolutivo onde o conhecimento empírico catalogado (de observação), ditou as regras da ciência clássica, cujos parâmetros continuam sendo aprimorados desde então. Ainda que diante da escassez de mecanismos auxiliares, da rudimentarização das ferramentas de trabalho e da não disposição de dados mais específicos que corroborassem com a comprovação dos estudos realizados, os cientistas falavam e acreditavam, por exemplo, na possibilidade de transmissão das características genéticas entre pais e filhos -, de modo que inúmeros estudos se seguiram nesta linha (DIAFÉRIA, 1999,

p.102).

A incansável busca pelo conhecimento e entendimento do processamento da vida no planeta, fez com que genuínos cientistas (a exemplo de Gregor Johann Mendel (18221884)) se debruçassem e dedicassem suas vidas ao progresso científico e ao bem comum. Tamanha dedicação, por vezes reconhecida post mortem, traçou os ditames do atual 
desenvolvimento científico, mesmo quando realizado em um tempo onde a tecnologia ainda não se fazia presente e as dificuldades eram consideráveis.

A evolução foi tamanha que, hoje, não mais se reage com estranheza a fatos que, há certo tempo, seriam inimagináveis. Presencia-se não apenas surpreendentes revelações a respeito do conhecimento teórico sobre a intimidade dos mecanismos de criação e reprodução da vida humana, como também uma rápida transformação destes conhecimentos em arrojadas inovações tecnocientíficas diretamente aplicáveis ao melhoramento da saúde e das condições de vida e, como almejam os mais entusiastas, a criação artificial da vida, da inteligência e da própria existência.

Tratando acerca do espírito investigativo dos cientistas, LEITE (2001, p.108) pondera que "se os pesquisadores procuram e sempre encontram novas propostas para o Homem, é porque desde tempos imemoriais a vontade de combater o sofrimento e a morte, assim como uma sede inesgotável de felicidade, persegue constantemente a vontade humana".

A partir desta base e ao lado do atualíssimo emprego da tecnologia no preparo e desenvolvimento das pesquisas, percebeu-se um incremento e uma maior variabilidade de possibilidades e resultados. Em um grande salto, conseguimos, por exemplo, conhecer e decodificar materiais genéticos, separando seus componentes, individualizando suas estruturas, conhecendo suas funções, combinando-as e recombinando-as em uma infinitude de procedimentos e técnicas. Tal possibilidade acabou rompendo com o paradigma inicial de observação, passando a transformar o que antes era considerado cenário de ficção em realidade. Em pouco tempo, passou-se da observação para a criação. Em especial o corpo humano e a vida humana fazem parte de uma intrigante e inquietante pesquisa que busca, incessantemente, a cópia ou o modelo de perfeição onde estejam garantidas, finalmente, a existência e a subsistência eterna.

Diante deste panorama, somos convidados a (re) pensar o atual papel da ciência na vida contemporânea e a importância de seu alcance:

[...] se a ciência hoje é uma manifestação sociocultural, que influencia nossa vida social, que modifica nossos sistemas e valores, não é somente por causa das novas representações que nos propõe à realidade, como a clonagem e seus reflexos, mas, principalmente porque gerou muitas práticas, técnicas e máquinas que transformaram nossa maneira de viver. E se toda mudança acarreta muitas consequências, em todos os níveis do conhecimento e da existência humana, toda humanidade precisa estar participando conscientemente desta nova etapa de sua própria evolução. (DIAFÉRIA, 1999, p.141). 
Indissociavelmente, ciência e tecnologia caminham juntas e interligadas, de modo que RIFKIN (1999, p.235-236) chega a conotar como "ferramentas" a combinação dos genes com os softwares e a vida como "trabalho de arte", ao dizer:

Juntos, o software e a rede genética, representam as "ferramentas de fabricação de imagem" fundamentais, nos permitindo usar as técnicas mais sofisticadas para transformar a vida em "trabalhos de arte". É compreensível que possamos preferir pensar nas novas tecnologias como ferramentas de artistas mais que ferramentas de engenharia, e em nós mesmos como trabalho de arte no processo mais que máquinas sendo afinadas [...].

Partindo-se de uma análise meramente conceitual, fica fácil perceber que quanto mais se avança nos campos da informática e da ciência, mais difícil será efetuar a distinção entre elas já que, por exemplo, no campo da bioinformática o ser vivo é considerado "[...] por um lado, enquanto texto, informação digital; por outro, enquanto vida, informação genética, como se o ser vivo fosse uma linguagem que se expressa tanto no plano abstrato, plano dos signos, quanto no plano concreto, plano na matéria viva”.

Promovendo uma considerável revolução na vida das pessoas, principalmente quando o enfoque é dado nas questões que envolvem a saúde humana, o casamento entre a ciência e a tecnologia produz reflexos que transpassam os muros científicos. Toda a sociedade e seus atores governamentais, econômicos, comerciais, educacionais, jurídicos, etc., voltam seus olhos com muito interesse para este novo seguimento, na tentativa de buscar compreender sua maneira de agir e sua abrangência. Assim, a humanidade vem sendo, pouco a pouco, convidada a reformular e alterar conceitos, revisar comportamentos. E é neste contexto que nasce a preocupação com o atuar do Estado no sentido de legitimar uma matéria que, em termos legais, já nasce com grandes lacunas, e que em curtos lapsos temporais, sofre intensa metamorfose, tornando-se "ultrapassada", frente ao incontrolável ritmo de desenvolvimento atingido pelas novas tecnologias.

Em pouco mais de uma geração, nossa definição de vida e o significado da existência estarão radicalmente alterados. Concepções há muito consolidadas sobre a natureza, incluindo nossa própria natureza, deverão ser repensadas. Muitas práticas antigas referentes à sexualidade, reprodução, nascimento e parentesco serão parcialmente abandonadas. Ideias sobre igualdade e democracia também serão redefinidas, bem como nossa visão do que significam "livrearbítrio" e progresso. (RIFIKIN, 1999, p.01) 
Mudanças consideráveis nas noções de igualdade e socialização vêm sendo marcantemente reformuladas. Cada vez mais juntos, ciência e tecnologia fazem com que as mais diversas combinações possam ser criadas e recriadas, a ponto de promover o intento de maior revolução que a humanidade já pôde viver e, na qual não pode prever seus impactos, diante da avaliação de seus inúmeros alcances.

Segundo MORIN (2000, p.59), “A história das ciências, como a de todas as ideias humanas, é uma história de sonhos irresponsáveis, de teimosia e de erros. Porém, a ciência é uma das raras atividades humanas, talvez a única, na qual os erros são sistematicamente assinalados e, com o tempo, constantemente corrigidos”.

Não há o que contestar em relação à importância da investigação tecnocientífica, com seus avanços e resultados positivamente alcançados. O homem, desde o início da sua caminhada evolutiva, procura o seu adiantamento, a sua evolução, tanto no aprimoramento dos meios materiais, quanto dos meios naturais e culturais, cuja jornada de aperfeiçoamento e inovação segue em ritmo alucinante. No entanto, entender os meandros da ciência e da tecnologia neste século é um grande desafio lançado a todos nós.

\section{DELINEAMENTOS BIOÉTICOS E O DIREITO - UMA REFLEXÃO NECESSÁRIA FRENTE ì INOVAÇÃO TECNOCIENTÍFICA}

Nunca foi tão urgente trazer à pauta a necessidade do conhecimento. Conhecimento que busca agregar as gerações a um fim comum de respeito, continuidade e preservação. E nesta busca pelo conhecimento integrado, passamos pelo desafio premente de reencaixar as ciências em um comando único e não mais individual, compartimentalizado. Integralização que busca nas razões epistemológicas e no debate interdisciplinar sua força, para que possamos nos preparar e resolver sobre aquilo que realmente queremos nos tornar e ser.

A tarefa é complexa, cheia de indagações, e os prognósticos, em que pese em sua grande maioria prometerem ótimos resultados, apresentam um alcance incerto fazendo com que o controle das novas tecnologias, a médio e longo prazo, seja mais incerto ainda. 
Ressalta-se que a tecnociência aplicada, acaba por inaugurar novos padrões de comportamento e arranjos orgânicos que vão sendo incorporados, no dia a dia das pessoas, alterando as sociedades e a maneira de conceber a vida sem, contudo, pedir licença (como por exemplo, a frequente utilização de organismos transgênicos, a possibilidade de inseminação artificial homóloga post mortem ou a aplicação terapêutica de nanobiossensores e de nanofármacos ${ }^{1}$ ).

Ao lado destes padrões ou da simples promessa de novos padrões, surgem as preocupações com o homem, com a sociedade e com o meio ambiente, já que são estes institutos (homem, sociedade e meio ambiente) os atores imediatos e sobre os quais os resultados se mostrarão. E é justamente neste contexto, que o alcance das novas tecnologias e o estudo aprofundado das questões éticas e bioéticas se faz necessário, pois busca aproximar os interlocutores (criador e criatura) de seus inventos, a partir de parâmetros de conduta legitimadoras do bem comum. Neste contexto, pode-se auferir que a Bioética, além de definir as diretrizes mínimas de aplicação da pesquisa tecnocientífica, inaugura as bases para que o Direito possa cumprir sua principal tarefa: a jurisdicional, ou seja, a de decidir e resolver conflitos.

É neste viés que a Bioética ${ }^{2}$ surge como ramo do conhecimento que se preocupa, preponderantemente, com as implicações ético-morais resultantes do avanço da ciência e da tecnologia e seus possíveis arranjos. A seu lado, faz-se necessária e fundamental a presença do Direito, como ciência que é, na tentativa de buscar regulamentar a posição do indivíduo em relação à sociedade e deste para com o Estado, uma vez que estes avanços/ineditismos repercutem consideravelmente no âmbito jurídico-estatal.

Assim, o desenvolvimento de uma Bioética e sua tutela jurídica, exige de nós, profissionais, pesquisadores e estudiosos, uma discussão histórica do poder da tecnociência em uma significativa economia de mercado (que tende ao crescimento), de maneira a resgatar a noção de dignidade humana, permitindo que a sociedade se torne parceira crítica de todas estas questões (LEITE, 2001, p.99). 
1 Para um melhor aprofundamento acerca destes conceitos, sugere-se a leitura do artigo escrito por Ana Rita Ramalho Figueiras, André Brito Coimbra e Francisco José Baptista Veiga, intitulado: Nanotecnologia na saúde: aplicações e perspectivas. Disponível em: <http://www.ojs.ufpi.br/index.php/geum/article/view/1729/1705>

2 Bioética "é um neologismo derivado das palavras gregas bios (vida) e ethike (ética)". Por definição é "o estudo sistematizado das dimensões morais - incluindo visão, decisão, conduta e normas morais - das ciências da vida e da saúde, utilizando uma variedade de metodologias éticas num contexto interdisciplinar". [grifo conforme original]. (DIAFÉRIA, 1999 , p.84). 
Diante da "deriva cientificista do direito" (PARDO, 2015, p.26) frente os riscos e incertezas postos pelos novos conhecimentos tecnocientíficos, torna-se, cada vez mais primordial a relação entre a Bioética e o Direito, cabendo a este resgatar nos princípios bioéticos sua base de construção, a fim de buscar entender e melhor responder às inúmeras indagações resultantes do desenvolvimento tecnológico.

Segundo LEITE (2001, p.116), “as questões relativas à bioética vêm, naturalmente, eivadas de complexidade porque, ao contrário de outras áreas do conhecimento, que podem se esgotar em uma visão reducionista, são também questões científicas, filosóficas, econômicas e jurídicas.”.

A visão contemporânea que ora se descortina afasta-se do antropocentrismo para o tecnocentrismo, no qual, o ser humano individualmente considerado ou inserido em sua coletividade, passa a ser projeto e não sujeito de direito. Mas o ser humano, "independente do estágio de evolução científica que se encontre, continua sendo ser humano, na sua mais integral e perfeita constituição", portanto, todos os "atos praticados sobre o ser humano, quer embrionário, quer adulto, não podem ser considerados, em níveis distintos, como pretendem certos segmentos científicos, ou com total liberdade, e sem nenhum controle" (LEITE, 2001, p.105).

A existência e o papel desempenhado pelos comitês de ética já demonstrou que o Direito não pode se impor por si mesmo; ou seja, a legitimidade jurídica é mediatizada pelo debate com os cientistas. O direito se constrói em relação a suas descobertas, mas também a partir dos riscos que as novas técnicas criam para a condição humana. É da interferência dos dois mundos, o científico de um lado (leia-se, biomédico) e o jurídico do outro, que, através de um processo lento, demorado e cauteloso, vão se determinando condutas, posturas e eventuais sanções aceitas por toda a comunidade humana. Relativamente aos riscos científicos oriundos das novas descobertas e das novas tecnologias, a experiência tem demonstrado que as normas da bioética são, primeiro, normas deontológicas, ou éticas - produzidas pelas organizações representativas dos cientistas e dos médicos - para, somente num segundo momento, ingressarem no terreno jurídico, na esfera da norma de cogência. A autonomia jurídica que sempre caracterizou a construção do Direito vê-se, pela primeira vez na história da humanidade, transferida para uma posição secundária, situação inédita a qual jamais algum jurista poderia supor a ocorrência. (CORDEIRO, 2001, p.99) 
O discurso bioético não se refere diretamente à questão das normas. Referese enquanto reflexão, na qual as questões éticas levantadas pelos problemas provocam as indagações relativas ao "o que fazer?, como assegurar o domínio social da produção, difusão e utilização das novas tecnologias de vida? (...) que nova concepção de homem se deverá consagrar socialmente?" (LEITE, 2001, p.109).

No afã de encontrar respostas é necessário ter em mente que:

O Direito, como ciência jurídica que é, encontra-se inserido "no processo das ciências em geral, vivendo as contradições de uma dogmática ora mais positivista, endossando uma estrutura de domínio econômico exploratório, ora mais jusnaturalista, prestigiando valores fundamentais, todavia o Direto - e, consequentemente, os operadores do Direito - têm uma vantagem sobre as demais ciências - é dotado de caráter normativo e, portando, coercitivo, tendo em seu dispor, no Brasil, uma Constituição que fixou o princípio da dignidade da pessoa humana como anteparo das investidas "técnicas" dos economistas, médicos, biólogos, físicos, sociólogos e até mesmo de juristas que atinjam, o supra-princípio absoluto, que é a dignidade humana (LEITE, 2001, p.117-118).

A interdisciplinaridade do tema é latente. Não restam dúvidas de que o desenvolvimento vertiginoso das novas tecnologias, principalmente nas áreas biomédicas, estão sendo os causadores da renovação do pensamento ético das questões daí oriundas. As diversas áreas do saber juntamente com a sociedade são convidadas a repensar o futuro e a discutir os possíveis rumos e tomadas de decisões em prol da coletividade, na tentativa de conhecer, entender e propor a redução dos riscos e das incertezas geradas por estas sofisticadas técnicas (VIEIRA e CARVALHO, 2006).

Várias das dificuldades atualmente enfrentadas decorrem da averiguação relativa ao aperfeiçoamento das novas tecnologias, a serviço da vida ou da saúde, que colocaram em cheque "as referências e medidas habituais e os fundamentos da moral e da deontologia que figuravam nos códigos jurídicos que regulavam a conduta humana" (LEITE, 2001, p.104).

O pensamento ético do final do século vinte foi norteado por assuntos relacionados com a conduta considerada 'certa' ou 'errada', 'boa' ou 'má' -, perfazendo a tarefa fundamental da ética. Hoje, além da preocupação com a conduta, as indagações atingem aspectos que vão além da técnica e alcançam bens transindividuais e transgeracionais.

Estas novas reflexões condizentes à bioética encontram, em seu campo de atuação, uma nova consciência relacionada aos direitos individuais e sociais, no tocante aos 
avanços científicos e tecnológicos atuais, podendo ser considerada um dos aspectos filosóficos mais importantes dos últimos tempos, sendo este o diferencial relativo ao pensamento ético do século vinte e um. Em outras palavras, a bioética é uma nova forma da ética aplicada, que busca caracterizar a sociedade, a cultura, a ciência, os comportamentos e os valores morais da civilização contemporânea. Em síntese, pode-se dizer que o termo Bioética está voltado à reflexão ética do fenômeno vida, sendo que seu verdadeiro papel ganhou notável destaque com o avanço da biologia molecular e das novas tecnologias (podendo-se citar aqui a atual vertente científica centrada no desenvolvimento, cada vez mais sofisticado, da biotecnologia e da nanotecnologia). Neste contexto, faz-se oportuno dizer que um dos compromissos da ciência é:

(...) gestar o futuro, antecipando-se a ele por meio de descobertas que venham realmente proporcionar benefícios e segurança à espécie humana. A mutabilidade da sociedade e do mundo é uma certeza; a dúvida reside em estabelecer o "limite" ou "ponto" concreto até onde (e em que momento) os avanços da ciência devam acontecer. Sendo conveniente recordar que a ética sobrevive sem a ciência e a técnica; sua existência não depende delas. A ciência e a técnica, no entanto, não podem prescindir a ética, sob pena de transformarem-se em armas desastrosas para o futuro da humanidade nas mãos de minorias poderosas e/ou mal-intencionadas (...) além de sua importância qualitativa (...) a ética serve como instrumento preventivo e prudencial contra abusos atuais e futuros que venham a trazer lucros abusivos para poucos, em detrimento do alijamento e sofrimento da maioria da sociedade (GARRAFA, 1999, p.288-289).

Assim, a Bioética, marcada pelo seu forte viés interdisciplinar, apresenta-se como uma nova disciplina do saber, que surge da necessidade de manifestar as novas relações humanas originadas das novas tecnologias e da possível transfiguração da vida, buscando algumas respostas aos dilemas enfrentados.

Sem dúvida é preciso ser arrojado, pesquisar, investigar. Contudo, na mesma medida em que a tecnologia dá passos largos em direção à modernização da produção científico- tecnológica, essa mesma tecnologia também apresenta (ou deveria apresentar) meios de verificar os efeitos oriundos das novas investigações. Em suma, é preciso avançar. Avançar com responsabilidade e respeito, principalmente, em relação ao ser humano

e ao meio ambiente. 


\section{BREVES DELINEAMENTOS DOUTRINÁRIOS}

De acordo com tudo o que foi estudado, constata-se uma realidade ainda não muito discutida pelo Direito Contemporâneo. Verifica-se um esforço do legislador em regular um assunto inédito, inovador e particularmente ligado à figura do ser humano tendo como aporte principal os preceitos e fundamentos constitucionais.

Firmados nos pilares principiológicos da Bioética $^{3}$ e do Princípio da Dignidade Humana, o legislador procura, por vezes, disciplinar uma matéria que nasce desatualizada e encontra-se em franco desenvolvimento e aperfeiçoamento -, neste ponto, arrisca-se dizer que a legislação apresenta-se confusa, ou seja, restritiva em alguns casos e permissiva em outros.

O jurista encontra, cada vez mais frequentemente, sérios obstáculos que, inevitavelmente, tem de enfrentar quando pretende analisar uma realidade social nova, sobretudo quando sua instauração é condicionada de forma decisiva pelos avanços científicos e tecnológicos. A dificuldade consiste numa comprovação muito simples: para levar a cabo com êxito a análise jurídica da realidade social que se propôs como objeto de estudo, é preciso que o jurista tenha um conhecimento o mais acertado e fiel possível de tal realidade ou, dito de outro modo, do assunto que é objeto da apreciação jurídica [...] mas [...] quando as inovações tecnológicas ou as descobertas científicas se apresentam como núcleo ou fundo daquelas relações, o jurista corre o risco de fracassar seu intento analítico, se não tiver realizado o esforço adicional de captar pelo menos os aspectos mais relevantes dessas inovações ou descobertas e o modo como verdadeiramente atuam nas relações humanas. (CASABONA, 2002, p.23).

Nota-se que o Direito se vê intrigado ao observar o futuro. A lógica do mercado, deveras dominante, acaba por transformar o homem em objeto e o Direito, inserido no processo das ciências em geral, encontra-se “[...] vivendo as contradições de uma dogmática ora mais positivista, endossando uma estrutura de domínio econômico exploratório, ora mais jusnaturalista, prestigiando valores fundamentais [...].” (LEITE, 2001, p.116-117).

Diante desta árdua tarefa, percebe-se que o Direito encontra-se aprisionado em seu eixo antropocêntrico positivista de certeza e segurança. $O$ surgimento e a propagação das novas tecnologias expuseram o fio mais frágil do Direito ante a expansão da incerteza nas sociedades contemporâneas. Esta exposição trouxe a necessidade de reformular e criar parâmetros próprios de decisão, tendo em vista que os atuais não são suficientes diante desta nova empreitada. 
${ }^{3}$ Princípio da Benificência, Princípio da Não maleficência e Princípio da Autonomia. 
Acredita-se que o surgimento de uma legislação por vezes flexível, mas em sua essência firme e atuante, "deve ser criada para controlar e regulamentar questões que, de há muito, estão a exigir uma normatização da sociedade". Constata-se que a intervenção de uma legislação "nunca foi tão desejada quanto atualmente, mas, contraditoriamente temida pelos juristas, cientistas, médicos e moralistas que se preocupam com a multiplicação de situações totalmente fora das normas geradas por técnicas cada vez mais sofisticadas da manipulação da vida e da morte” (LEITE, 2001, p.116).

Desde os primórdios, como visto inicialmente, o homem busca com suas pesquisas atender as suas necessidades procurando obter melhores condições de vida e de saúde. Tanto as atualíssimas biotecnologias quanto as nanotecnologias provam o tamanho desta evolução. Todavia, ainda que diante de um progresso científico deveras promissor, deve-se ter em salvaguarda os limites da ética e da dignidade humana (SCAVOLINI, 2004, p.26).

Cada vez mais interligados, "ciência" e "tecnologia" são componentes de uma potente vertente revolucionária do que, em pouquíssimo tempo, será a maneira de entender e encarar o que é e será humano. Representando a consagração do conhecimento especializado, a ciência define os planos de ação de modo a tornar-se um referencial regulatório. O Direito vê- se atrelado à ciência e, neste ponto, diante dos incalculáveis riscos que estas novas tecnologias dão conta, carece de parâmetros para fundamentar sua própria razão de ser: a de decidir e resolver conflitos.

As bases científicas fundadas no discurso expert (especializado) ao lado dos interesses comerciais que a seara científica provoca, fundamentada em uma lógica econômica globalizada, acaba formando um poder (de mercado) regulatório de grande expressividade, uma vez que quem define os contornos que serão explorados é o próprio interesse comercial/econômico. Por isso, a importância impar do debate Bioético e da participação atuante da sociedade nos assuntos desta natureza, onde as incertezas são muitas.

Apresentando uma perspectiva Taoísta construtivista e reintegradora do ser humano com a natureza, FAGUNDES (2006, p.142) acertadamente leciona que: 
O Direito novo desperta para a multidisciplinaridade, reconhece a conexão dos saberes e destaca a principiologia para a solução dos problemas jurídicos.

O campo social dos Direitos Humanos configura uma "possibilidade de se unir o público e o privado, numa preocupação de ética, política, cultura e sociedade, a fim de conciliar os interesses individuais e os coletivos", de forma que "[...] se mostra adequado para mediar os interesses dos laboratórios e investidores particulares e os efetivos interesses coletivos [...]”. (ENGELMANN, 2010, p.659).

Como bem considera SARTORI (2015), “ao Direito não cabe impor barreiras ou estabelecer divisas morais e religiosas intransponíveis, mas sim disciplinar fatos que, inevitavelmente, venham a surgir em decorrência da evolução humana".

A inexistência de uma "pesquisa orientada para a elucidação dessa complexidade com os tempos curtos dos mercados financeiros e das exigências empresariais num ambiente de competição feroz" (SANTOS, 2006, p.64), contribui para que leigos, cidadãos, os próprios cientistas e o Estado se mobilizem para:

\footnotetext{
Suscitar interrogações de caráter ético [...] e preocupações com as consequências sanitárias, sociais, ambientais e econômicas destas práticas: tentativas de encontrar novas formas de regular e governar a inovação biotecnológica e biomédica e as suas consequências e de submeter ao debate e deliberação democrática as decisões sobre a aceitabilidade social das inovações e a definição de prioridades de investigação destes domínios (SANTOS, 2006, p.64).
}

LEITE (2001, p.105) afirma que "os atos tecnocientíficos praticados sobre o ser humano, quer embrionário, quer adulto, não podem ser considerados em níveis distintos, como pretendem certos segmentos científicos, ou com total liberdade e sem nenhum controle". Seguindo este mesmo entendimento, PEGORARO (1999, p.105) acrescenta:

\begin{abstract}
Estes atos são eticamente válidos desde que feitos segundo o respeito e a beneficência devidos ao ser humano em qualquer estágio. Isto porque um ser humano embrionário, fetal ou adulto é sempre um ser humano e nunca uma coisa [...] (porque) nosso corpo é sempre humano no seu todo e em cada uma de suas partes [...] (porque) qualquer que seja o estágio de sua evolução, o ser humano está situado no ponto mais adiantado da evolução e, por isso, revestido do grau mais elevado de eticidade.
\end{abstract}

Mesmo diante de grandes desafios, deve-se ter em mente que os avanços científicos continuarão e culminarão no surgimento de novas tecnologias cada vez mais sofisticadas, devendo-se assumir, hoje e sempre, uma postura firme quanto aos eventuais 
abusos relativos às suas técnicas. Assim, percebe-se que se está no limiar de um desafio, por vezes indeclinável da condição humana: compartilhar o controle da atuação científica no sentido de evitar sérios e inaceitáveis abusos contra a vida e aos princípios que a ela socorrem.

\section{AS (IN) CERTEZAS DA EXPLORAÇÃO TECNOCIENTÍFICA E AS RAZÕES DE DECIDIR - UM NOVO PARADIGMA}

Não é demais ressaltar que o progresso científico é desejável, mas deve vir acompanhado das preocupações com relação à sociedade e ao meio ambiente. Conforme inicialmente apresentado, o homem evoluiu em sua ânsia pelo conhecimento de maneira incomensurável, a ponto de podermos falar no incremento tecnológico como um novo marco científico, possível, legítimo e real.

Tamanho salto nos fez passar de criatura a criador, no entanto, a previsão das consequências desta ruptura são cada vez mais incertas. A escassez de dados que orientem quanto aos aspectos negativos a estas novas tecnologias, acabam por abrir um campo de riscos ao homem, ao meio ambiente e, quiçá, a própria vida neste planeta.

Diante deste cenário, a construção de previsões precisas sobre fenômenos futuros, na atual sociedade de risco (BECK, 2011), não tem seu fim atingido, uma vez que os riscos oriundos das novas tecnologias são abstratos (invisíveis e imprevisíveis), não havendo certezas científicas quanto aos seus reais alcances e resultados.

Assim, as incertezas são uma constante nas sociedades pós-modernas, conjugando um "formidável desafio que a expansão da incerteza científica propõe ao Direito e às instâncias políticas com responsabilidades de decisão" (PARDO, 2015, p.30).

Calcada inicialmente no campo das certezas, hoje, a própria ciência reconhece as suas grandes margens de incerteza que a impedem da emissão de um veredito certo e objetivo -, ainda que não seja ela a detentora do poder de decidir. Assim, a atividade científica passa ao domínio da linguagem das probabilidades, recusando-se a resolver suas próprias incertezas. Por sua vez, ao Direito cabe a nata e árdua tarefa de decidir, resolver, gerar e manter certezas -, não sendo dado a ele nenhuma possibilidade de manter-se na incerteza (PARDO, 2015, p.36-38).

Embora envolto em grandes desafios sem respostas, ainda assim, o Direito mostra "[...] um fascínio pela ciência que o enfraquece na defesa de bens e valores que lhes são encomendados", sendo incapaz de perceber "as transformações ocorridas no 
mundo da ciência, dominado por uma tecnociência atenta especialmente à rentabilidade das suas inovações e ante a qual ele teria que adotar uma postura mais rigorosa, pelo menos, em relação às suas promessas" (PARDO, 2015, p.46).

Neste contexto, cumpre reiterar que o Direito não se coloca em oposição ao progresso científico. Contudo, a partir do momento em que a ciência se afasta das certezas e encontra assento no terreno das probabilidades, falta ao Direito um apoio técnico firme para fundamentar suas decisões. E aqui podemos tratar de um marco que vai além de todas as novas tecnologias, pois condiz a assuntos complexos, de amplo caráter interdisciplinar e, até mesmo, transgeracional.

\begin{abstract}
Assim, restam mais dúvidas do que certezas. Este é um ponto fundamental para a regulação das nanotecnologias: ao invés da certeza e previsibilidade do modelo positivista, o Direito passa para uma nova etapa onde a incerteza e a imprevisibilidade do comportamento das partículas e dos seus efeitos acompanharão o processo regulatório. Ao invés de previsões gerais e prévias, o mundo jurídico deverá produzir respostas alinhadas constitucionalmente para cada caso em concreto, levando em consideração justamente a fluidez das nanopartículas e de suas características e interações sempre inusitadas. (HOHENDORFF e WUNSCH, 2015).
\end{abstract}

Novas coordenadas de decisão apresentam-se abertas pela ciência, cuja dimensão temporal percorre o futuro e o passado de forma livre e fluente, alterando as referências com as quais nos autocompreendemos. Para o passado, pois diante de uma incerteza superveniente, os novos conhecimentos científicos acabam por revisar parâmetros tidos como válidos e sobre os quais, de alguma forma, já se decidiu (favoravelmente ou não) -, ponto em que se traz à baila o exemplo do uso do amianto, cientificamente comprovado como prejudicial à saúde, mas por um grande período, livremente comercializado. Para o futuro, uma vez que a carga das decisões não mais atingem as gerações presentes, mas sim as futuras (caráter transgeracional), herdeiras das incertezas e de técnicas imprevisíveis quanto aos seus reais resultados (PARDO, 2015, p.57-64).

Diante deste panorama, a única certeza é de que ao Direito é dada a tarefa de tomar decisões e recriar seu poder de decisão sobre as bases de uma ciência geradora de incertezas. O arcabouço legislativo atual não consegue acompanhar o progresso científico, a ponto de aproximar-se da tão desejada efetividade e segurança jurídica (valores intrínsecos e estruturantes do Direito). 
Como ter e manter a efetividade e segurança jurídica quando o assunto diz respeito ao implemento incontrolável das novas tecnologias? Eis o desafio que se impõe!

De outro norte, percebe-se que o mesmo desenvolvimento científico voltado ao fornecimento de maior segurança e qualidade da vida humana, atinge a capacidade de destruir todo o planeta com um simples apertar de botão ou pela disseminação de organismos mutacionais nocivos -, fato não perceptível no século XVIII, já que o desaparecimento da humanidade ou eventual destruição do mundo eram totalmente atribuídos a desastres ou forças naturais e as pesquisas limitavam-se a simples aplicação empírica do conhecimento.

A ciência clássica tradicional objetivava a busca da verdade pelos critérios do cientista e pela simples observação dos resultados. Alcançada a verdade, abria-se espaço para a aplicação técnica destas verdades, que geralmente se desenvolviam ao longo do tempo (quando muito, tardiamente) e por pessoas e empresas geralmente alheias ao universo da investigação científica. Hoje, conforme dito, a ciência abandonou a certeza e encontra-se orientada por uma tecnociência que se preocupa, preponderantemente, com objetivos previamente determinados e com critérios de utilidade e rentabilidade de um mercado inteiramente voltado ao lucro e projeção individual.

O desafio da decisão na incerteza resulta premente para o direito, especialmente sob a pressão de dois elementos. O primeiro marca o próprio ritmo do desenvolvimento tecnológico que seguirá propondo, previsivelmente com uma sequencia mais acerada, novos cenários de incerteza. O segundo é imposto pela inércia de um sistema jurídico positivista, que foi construído justamente sobre o paradigma oposto, o da segurança jurídica, o da certeza das referencias fornecidas pelas normas, pelas declarações da administração ou as resoluções dos tribunais; um sistema jurídico que encontra, assim, muitas dificuldades e contradições quando se tem de operar na incerteza. (PARDO, 2015, p.69-70).

Este cenário acaba nos mostrando que a investigação científica decide sobre aquilo que é dado ao poder político decidir. Seu poder de decisão política é parte de um sistema que cada vez mais tem se tornado a regra e vem ganhando uma força gigantesca em termos de dominação. Nos espaços marcados pela complexidade técnica pode-se dizer que o poder político encontra-se condicionado e prisioneiro da pesquisa científica; esta última, marcada, organizada e programada dentro de poderosas estruturas empresariais e industriais. 
Ao cientista não é dado mais decidir sobre as linhas e objetivos da pesquisa. Hoje, ao contrário do que se praticava na ciência clássica tradicional, a aplicação técnica antecede a busca pela verdade e pela investigação voltada ao fim comum. Primeiro serão exploradas e quantificadas, o quanto possível, as análises de aplicação e aproveitamento e, com base nestas previsões, se decidirá se a investigação seguirá por uma ou outra linha, desde que compatíveis com o apoio financeiro necessário às suas previsões de rendimento.

Começa-se a perceber que o conhecimento está "deixando de ser um bem aberto ao interesse geral, acessível sem reservas aos poderes públicos, para se tornar uma mercadoria calculadamente produzida e apresentada em atenção a determinados interesses privados e comerciais", destacando-se, nesta linha de visão, uma das características mais salutares da tecnociência “a sua pretensão de influir sobre a sociedade e de dominá-la sempre que possível" (PARDO, 2015, p.104-105).

É chegada a hora de reconstruir a liberdade científica em sua dimensão pessoal mais genuína, ou seja, do cientista. (PARDO, 2015, p.125). A liberdade de investigação é um direito Constitucional e, como tal, deve permanecer e ser respeitada. Contudo, deve-se lutar por uma margem de atuação ampla da investigação que proporcione mais conhecimento e uma maior margem de escolha para as autoridades públicas com responsabilidades de decisão, fazendo com que o Direito recupere sua capacidade de domínio, frente a um marco jurídico favorável à liberdade e a igualdade.

Nesse diapasão, o que se vê é uma ciência que amplia, cada vez mais, a autoridade de seu conhecimento sobre a insegurança das instancias públicas. Por possuir pleno e efetivo domínio sobre as linhas de investigação, que se abrem ou se fecham atendendo a interesses lucrativos (por vezes, não científicos), percebe-se um esvaziamento do conteúdo material das normas jurídicas que acabam por se concentrar, basicamente, em aspectos formais ou de procedimento, sendo que as determinações materiais substantivas encontramse nas mãos dos experts da tecnociência.

Subjaz a necessária retomada pelo Direito de seus espaços próprios de decisão, reinstalando-se seus valores e referenciais, pelo que PARDO (2015, p.131-132) denomina as razões para recomposição do curso decisório, tendo-se em mente que: 1) são as instâncias públicas, imbuídas da necessária legitimação constitucional, que devem tomar decisões e ter um maior controle sobre elas; 2) o poder decisório das instâncias públicas legitimadas acaba por expressar a capacidade de autodisposição de uma sociedade; 3) 
as decisões adotadas devem ser genuinamente provindas dos órgãos jurídicos e não dos fundamentos científicos que os influenciaram, ou seja, torna-se inadmissível que decisões importantes sejam tomadas por técnicos com absoluto desconhecimento das instâncias políticas representativas. Como bem observa este autor:

Tal como acontece com alguma frequência nos tempos atuais, nos encontramos com uma posição constante e inalterada do Direito ante uma realidade que se transformou profundamente. Não variaram, assim, os pronunciamentos constitucionais sobre a ciência; é, no entanto, a ciência que mudou, e muito, até tornar-se quase irreconhecível ao olhar autista do Direito (PARDO, 2015, p.81-82).

Partindo de uma orientação cientificista (que confia o acerto de sua decisão ao que se considera a melhor categorização científica e técnica), o Direito continua fascinado pela ciência e seus conceitos, mesmo em cenários de incerteza e complexidade científica. Submerso em sua visão antropocêntrica (positivista e garantidora), acaba por fixar parâmetros que utilizam a "melhor técnica" como solução ao caso concreto; o que denota sua incapacidade de resolver e assumir parâmetros natos de controle (PARDO, 2015, p.161-163). Assim, o ideal de afirmação do Direito sobre a técnica, acaba sendo um rendimento a ela, de modo que:

[...] Pertence à própria essência da ação de decidir, um conhecimento mínimo sobre as opções colocadas para escolher entre algumas delas; se esse conhecimento não existe, já não se pode falar propriamente de decidir, mas de aventurar-se ao azar. A participação, portanto, do conhecimento especializado, do conhecimento científico, é totalmente imprescindível. Mas o que sim deve ser decidido pelo sistema jurídico é a correlação que se estabelece entre a ciência e o direito, entre as instancias científicas e os poderes públicos, e reter esta capacidade ordenadora evitando a total entrega, que é a tendência hoje dominante, ao que a ciência estabeleça, com o grave inconveniente de que a ciência pode manter, com toda lógica e coerência, que a ela lhe corresponde a busca e expansão do conhecimento, mas não a obrigação e a responsabilidade da decisão (PARDO, 2015, p.136).

Seguindo a linha crítica acerca da orientação cientificista, PARDO (2015, p.181) afirma que "o direito acaba por renunciar aos protocolos e modelos de decisão que lhe são próprios e, sobretudo, renuncia também à sua função própria de dotar de legitimidade e segurança essas decisões e regulações", dando ensejo ao surgimento das seguintes objeções: 
1) a utilização massiva e remissiva à tecnociência produz ainda mais incertezas, tendo-se em vista o caráter nato destas ciências na produção de incertezas; 2) frequente aumento das decisões negativas ou de exceção; 3) perda e enfraquecimento da segurança jurídica; 4) surgimento de um regime de responsabilidades pelas decisões dos poderes públicos em situações de incerteza.

E neste cenário de objeções é dado ao Direito reconquistar e recriar seu "potencial de ficção" (como, por exemplo, o fortalecimento das presunções - presunção de inocência -, das máximas de experiência, da inversão do ônus da prova, da aplicação da equidade por parte do legislador, no lugar da certeza), uma vez que sua orientação e suas decisões não precisam corresponder à realidade/verdade objetiva criada empiricamente pela ciência. Diante da não sujeição do conhecimento científico a valores absolutos, o resgate dos princípios Bioéticos e o fortalecimento do Princípio da Dignidade Humana tornam-se vetores de orientação basilares e necessários em tempos de decisões na incerteza (PARDO, 2015, p. 192-200).

Frente a uma crise criada pela própria ciência que abriu mão de formular certezas, urge a necessidade de entrelaçamento dos diversos campos do conhecimento, de modo que, ao afastar a compreensão estritamente normativa do Direito, este não seja "apenas um instrumento de controle ou de aprisionamento do indivíduo", mas que possa servir de estímulo a condutas sociais positivas. FAGUNDEZ (2000, p.140).

Ainda que estejamos diante de um regime jurídico de responsabilidade rígido (oriundo de uma sociedade não industrializada e com baixo potencial de risco, cuja base fixa-se na ideia de culpa), o fato é que o desenvolvimento científico e tecnológico (fortalecido pela Revolução Industrial que inovou e ainda inova no seu desenvolver, trazendo um alto potencial de risco que não mais encontra na intervenção culpável a resolução dos danos) não se deteve por ele.

Respondendo a razões e estímulos muito diversos, em sua maioria voltados ao mercado lucrativo que representa, restou num plano distante a vontade desinteressada em melhorar a vida das pessoas em prol do benefício da sociedade em seu conjunto (como valor universal). Contudo, mesmo diante desta realidade, apenas ao Direito é dada a tarefa de decidir e buscar parâmetros próprios, com base em seus preceitos, princípios, fundamentos, presunções e ficções, para que se mantenha íntegro 
nesta grandiosa tarefa, resgatando a segurança em situações de incerteza e fortalecendo a sua certeza que tanto lhe é peculiar.

\section{CONCLUSÃO}

Evoluímos. E com essa evolução novos conceitos e desafios são lançados dioturnamente já que a incansável busca pelo melhoramento humano move o espírito investigativo do cientista levando-o a situações cada vez mais inusitadas. Neste contexto, o surgimento da tecnologia e implementação de suas técnicas no campo científico encerra uma das mais promissoras escaladas ao novo, ao inédito. E é justamente este ineditismo que nos lança ao desafio de entender os liames desta ciência criadora de novos conceitos, concepções de vida e de saúde, na tentativa de formar as bases para a reflexão essencial, e não menos importante, do papel do Direito em tempos de (in)certeza.

A tecnociência, em sua via mais intrínseca, reconhecendo sua fragilidade premente na criação de certezas e, na tentativa de minimizar os riscos e responsabilidades, mudou consideravelmente seu prognóstico trabalhando com 'probabilidades' no lugar de 'certezas'. De outro norte e a contrário sensu, a constatação deste fato não reduz e não exime o dever das instancias públicas de tomarem decisões quando chamadas a decidir em ambientes de incerteza, garantindo aos jurisdicionados uma solução certa, segura e definitiva destes conflitos.

O fortalecimento dos princípios Éticos, Bioéticos e dos preceitos constitucionais que cuidam da pessoa humana ganham relevo e devem orientar toda a órbita jurídica a fim de que sejam criados mecanismos de decisão próprios que resolvam os desafios impostos. Esta urgência em romper com as amarras científicas decorrentes das novas tecnologias (que nos insere, cada vez mais, em uma obrigação de imediatismo não racional, de obrigação de quase 
'consumo') remete-nos ao desafio jurídico de encontrar uma razão e um método legítimo de enfrentamento destas questões em situações de incerteza. Ao Direito não é mais dada a possibilidade de manter-se como mero expectador das razões científicas apresentadas pelas novas tecnologias e pautar-se por elas (como única fonte expert legitimadora), pois a ele é dado o poder de decidir, não com base em probabilidades, mas com base na criação, geração e manutenção das certezas jurídicas.

Não se está a afirmar, com isso, que o progresso tecnocientífico é indesejado ou que devamos criar limites legislativos que impeçam o andamento das pesquisas. Ao contrário. É preciso dar o mesmo poder científico ao Direito e às instâncias públicas encarregadas de efetivar seu comando decisório, criando bases sólidas que, ao lado das tecnocientíficas, possam resguarnecer e fortalecer o cientista, o jurista e, principalmente, o bem comum de todos -, inclusive e primordialmente, em situações de incerteza.

Longe de esgotar esta temática, que carece de novos estudos e aprofundamentos, chega-se à conclusão de que é preciso pautar-se pelo empoderamento da Ciência do Direito na criação de matrizes de decisão que fortaleçam seus institutos ou na recriação dos existentes, a fim de que os interesses dissociados da compreensão e alcance da tecnociência sejam controlados e para que haja o fortalecendo de seus próprios institutos a partir da dogmática do "dever ser" do Direito.

\section{REFERÊNCIAS}

BECK, Ulrich. Sociedade de risco: rumo a uma outra modernidade. São Paulo: Editora

34, 2011.

CASABONA, Carlos María Romeo. Genética e Direito. In: CASABONA, Carlos María Romeo (Org.). Biotecnologia, Direito e Bioética: Perspectivas em Direito Comparado. Belo Horizonte: Del Rey e PUC Minas, 2002.

CORDEIRO, Renato Sérgio Balão. A responsabilidade institucional. A moralidade dos atos científicos; apud: LEITE, Eduardo de Oliveira. O direito, a ciência e as leis bioéticas. In: SANTOS, Maria Celeste Cordeiro Leite (Org). Biodireito: ciência da vida, os novos desafios. São Paulo: Revista dos Tribunais, 2001.

DIAFÉRIA, Adriana. Clonagem, aspectos jurídicos e bioéticos. São Paulo: Edipro, 1999. ENGELMANN, Wilson. Direitos Bio-Humano-Éticos: Os humanos buscando 'Direitos' para 
proteger-se dos avanços e riscos (desconhecidos) das nanotecnologias. In: Nacional de Pesquisa e Pós-graduação em Direito, 2010, Fortaleza-CE. Anais do XIX, Encontro Nacional do CONPEDI, 2010. Disponível em:

<http://www.publicadireito.com.br/conpedi/manaus/arquivos/anais/fortaleza/3400.pdf> Acesso: 10 jul. 2015.

FAGÚNDEZ, Paulo Roney Ávila. O Novo (em) Direito. Florianópolis: OAB Editora, 2006.

FAGÚNDEZ, Paulo Roney Ávila. Direito e Holismo: introdução a uma visão jurídica de integridade. São Paulo: LTr, 2000.

GARRAFA, Volnei. Transgênicos, ética e controle social. In: Revista O mundo da saúde. Vol.23, n.5. São Paulo: União Social Camiliana, 1999.

HOHENDORFF, Raquel Von; WUNSCH, Guilherme. As nanotecnologias e os seus impactos na sociedade e no mundo do trabalho. Disponível em:

$<$ http://emporiododireito.com.br/as-nanotecnologias-e-os-seus-impactos-na-sociedade-e-nomundo-do-trabalho-por-guilherme-wunsch-e-raquel-von-hohendorff/> Acesso: 23 nov. 2015.

LEITE, Eduardo de Oliveira. O direito, a ciência e as leis bioéticas. In: SANTOS, Maria Celeste Cordeiro Leite (Org.). Biodireito: Ciência da vida, os novos desafios. São Paulo: Revista dos Tribunais, 2001.

MORIN, Edgar. Ciência com consciência. Rio de Janeiro: Bertrand Brasil, 2000.

PARDO, José Esteve. O desconserto do Leviatã: política e direito perante as incertezas da ciência. São Paulo: Inst. O Direito por um Planeta Verde, 2005.

PEGORARO, Olinto A. O que é o ser humano? In: CARNEIRO, Fernanda (Org.). A moralidade dos atos científicos - questões emergentes dos comitês de ética em pesquia. Rio de Janeiro: FIOCRUZ, 1999.

RIFKLIN, Jeremy. O século da biotecnologia: a valorização dos genes e a reconstrução do mundo. São Paulo: Makron Book, 1999.

SANTOS, Boaventura de Sousa. A gramática do tempo: para uma nova cultura política. São Paulo: Cortez, 2006, v.4.

SARTORI. Ivan Ricardo Garisio. Células Tronco. O direito. Disponível em: <http://jus.com.br/artigos/7186/celula-tronco-o-direito> Acesso: 21 set. 2015.

SCAVOLINI, Francisco. Dolly e os embriões humanos. Revista Jurídica Consulex. Ano 
VIII, n. 180, 15 de julho/2004.

VIEIRA, Ricardo Stanziola; CARVALHO, Ester de. Direitos Humanos e Biotecnologia: aspectos dilemáticos contemporâneos. In: Revista Novos Estudos Jurídicos. Vol.11, n.1. Itajaí: Universidade do Vale do Itajaí, 2006. 